\title{
Alectoria spinosa, a new lichen species from Hengduan Mountains, China
}

\author{
Wang LS ${ }^{1}$, Liu $D^{1}$, Shi HX ${ }^{2}$, Zhang YY ${ }^{1}$, Ye $X^{2}$, Chen $\mathrm{XL}^{3}$ and Wang XY' \\ ${ }^{1}$ Key Laboratory for Plant Diversity and Biogeography of East Asia, Kunming Institute of Botany, CAS, Kunming, \\ Yunnan 650204, China \\ ${ }^{2}$ Yunnan University of Traditional Chinese Medicine, Kunming, Yunnan 650500, China \\ ${ }^{3}$ Institute of Applied Ecology, Chinese of Sciences, Shenyang 110016, China
}

Wang LS, Liu D, Shi HX, Zhang YY, Ye X, Chen XL, Wang XY 2015 - Alectoria spinosa, a new lichen species from Hengduan Mountains, China. Mycosphere 6(2), 159-164, Doi 10.5943/mycosphere/6/2/6

\begin{abstract}
Based on inferences from morphological, chemical and phylogenetic analysis using ITS sequences, a new species of Alectoria is described from the Hengduan Mountains in southwestern China, A. spinosa Li S. Wang \& Xin Y. Wang sp. nov, it has dull yellowish fruticose thallus with abundant pseudocyphellae, which is the main character of Alectoria, and differs from all the other Alectoria species by having isidia-like spinules on the soralia. Two species of Alectoria are confirmed in China, their morphological and chemical traits, together with their geographical distributions in China, are discussed, and a key to the species is provided.
\end{abstract}

Key words - Lichenized fungi - Parmeliaceae - phylogeny - taxonomy

\section{Introduction}

Alectoria Ach. (Parmeliaceae, Lecanorales; Tehler \& Wedin 2008), typified by Alectoria sarmentosa (Ach.) Ach., is characterized by having light yellow-brown to dull yellow, fruticose, caespitose, erect to pendulous thalli, attached by a holdfast and dichotomously to irregularly branched; thalli with raised pseudocyphellae and a cortex composed of periclinal, conglutinate hyphae; medullary hyphae loose and usually verrucose, lacking a central axis; apothecia lecanorine; ascospores 1-celled, ellipsoid, turning brown or dark brown when mature, 2-4 per ascus; photobiont green algae (trebouxioid); and containing usnic, diffractaic and alectoronic acids as the major secondary compounds (Hawksworth 1970). Alectoria differs from Sulcaria Bystrek by lacking longitudinal furrows on the surface, from Oropogon Th. Fr. and Bryoria Brodo \& D. Hawksw. by having brown spores and containing usnic acid in the cortex.

The genus currently contains seven species worldwide; most of the species historically reported as Alectoria were placed in Bryoria (Brodo \& Hawksworth 1977, Halonen et al. 2009). Alectoria has a bipolar and arctic-alpine distribution (Brodo \& Hawksworth 1977). One species was previously known from China (Alectoria ochroleuca (Hoffm.) A. Massal.; Wei 1991).

Preliminary studies on the taxonomy of Alectoria in China have been completed (Wu \& Wang 1992, Wang et al. 2014). During these studies, an undescribed species of Alectoria was discovered in the Hengduan Mountains. We confirmed the placement of this new species in 
Alectoria with morphological, chemical, and phylogenetic analyses. A description of this species and a key to both Alectoria species in China is provided.

\section{Materials \& Methods}

Specimens used in this study were collected from China between 1981 and 2014, and are deposited in the Herbarium of Kunming Institute of Botany, China (KUN-L). Specimens were examined using standard microscopic techniques and hand-sectioned under a Nikon SMZ 745T dissecting microscope. Anatomical descriptions are based on observations using a NIKON Eclipse 50i microscope, and structures were photographed using a Nikon digital camera head DS-Fi2. Size ranges are provided as smallest-largest single value recorded.

Secondary metabolites of all the specimens were identified using spot tests and TLC as described by Orange et al. (2001). Solvent C (toluene: acetic acid = 85:15) was used for TLC analysis.

Total DNA was extracted from small fragments of fresh thallus (Table 1.) following the protocol by Ekman (1999) using the Axyprep Multisource Genomic DNA Miniprep Kit. The nrDNA ITS region (ITS1-5.8S-ITS2) was amplified by PCR using the ITS1F (Gardes \& Bruns 1993) and ITS4 (White el al. 1990) primers. Previously described conditions by Arup (2002) were used for PCR: $2 \mu$ l of genomic DNA was added to the following mix: $2 \mu 1$ of primer $(1 \mu 1$ for each primer of a $10 \mathrm{mM}$ solution), $12.5 \mu \mathrm{l} 2 \times$ Taq PCR Mastermix (Aidlab) (containing Taq DNA Polymerase: 0.1 unit/ $\mu \mathrm{l} ; \mathrm{MgCl}_{2}: 4 \mathrm{mM}$; dNTPs: $0.4 \mathrm{mM}$ ) and $8.5 \mu \mathrm{dH}_{2} \mathrm{O}$ for a total volume of 25 $\mu$ l. Amplifications were carried out in a thermocycler (C 1000TM), with the following profile: initial denaturation at $94^{\circ} \mathrm{C}$ for $5 \mathrm{~min}$, followed by 30 cycles, each of three steps $\left(94^{\circ} \mathrm{C}\right.$ for $1 \mathrm{~min}$, $56^{\circ} \mathrm{C}$ for $1 \mathrm{~min}, 72{ }^{\circ} \mathrm{C}$ for $1.5 \mathrm{~min}$ ), and a final extension at $72^{\circ} \mathrm{C}$ for $7 \mathrm{~min}$. PCR products were precipitated and sequenced using ABI Applied Biosystems 3730 DNA Analyzer (Foster City, California, U.S.A.) with the same primers as the original PCR amplifications..

Raw sequences were assembled and edited using SeqMan (DNAstar packages), then sequences were automatically aligned with MUSCLE v3.6 (Edgar 2004). GBLOCKS (Castresana 2000) was used to evaluate ambiguous regions using the default settings. Bayesian inference (BI) and Maximum likelihood (ML) are used to reconstruct the phylogenetic tree, with Gowardia arctica as the outgroup. All characters were equally weighted and treated as unordered.

For BI, model selection was based on the Akaike information criterion (AIC) estimated by jModelTest 3.7 (Posada 2008), analyses were performed with MrBayes v3.1.2 (Ronquist \& Huelsenbeck 2003) using the Metropolis-coupled Markov chain Monte Carlo method (MCMCMC). The initial burn-in was set to 50\%. A 50\% majority-rule consensus cladogram was computed from the remaining trees; the proportions of this tree correspond to Bayesian posterior probabilities (BPP), and clades with $\mathrm{PP} \geq 0.95$ were considered to be significantly supported. ML tree searches and bootstrapping were performed with RAxML v7.2.6 (Stamatakis 2006.). All parameters in the ML analysis used the default setting, and statistical support values were estimated by 1000 bootstrap replicates.

\section{Results}

Related genera Bryoria, Oropogon and Sulcaria were included in the phylogenetic analysis, in order to get a clear phylogenetic relationship of the new species. The phylogenetic inference places the putative new species within the clade of the genus Alectoria, and it formed a highly supported clade (MLBS: 100\%; PP: 1.0; Fig. 1), sister to A. ochroleuca, A. sarmentosa (Ach.) Ach. and $A$. imshaugii Brodo \& D. Hawksw. The three species formed a well-supported group (MLBS: 96\%; PP: 1.0; A. ochroleuca, A. sarmentosa and A. imshaugii) without soredia on thallus and lateral spinules on the soralia, while $A$. spinosa formed another clade and differs by having spinules on soralia. Based on morphological, chemical and molecular investigations, the new species Alectoria spinosa is presented. 
MycoBank

Etymology - The epithet "spinosa" refers to the spinules on the soralia of the thallus.

Type - CHINA, Yunnan: Lijiang Co., Jiuhe Village, Laojunshan Mt., 26³8.186' N, 99 $44.077^{\prime} \mathrm{E}, 4150 \mathrm{~m}$, on the bark of Rhododendron, 25 June 2014, Li S. Wang 14-44046 (KUN-L 45926, Holotype)

Synopsis - Corticolous Alectoria with spinules growing on the soralia, light yellowish brown thallus with usnic and virensic acids.

Description - Thallus fruticose, forming clusters, tufted, $1.5-3.0 \mathrm{~cm}$ tall, yellowish brown to brown, dark brown towards the apices, the basal part black, carbonized; main branches $0.3-0.5$ $(-1) \mathrm{mm}$ in diam., cylindrical to flattened, densely branched with dichotomous branching; spinules rare, $0.1-0.5 \mathrm{~mm}$ long, branched at maturity, concolorous with the thallus; soredia granulose, isidia-like spinules growing on the soralia, $0.1-0.5 \mathrm{~mm}$ long; pseudocyphellae abundant, fissureshaped, grayish white to light brown, $0.2-1.2 \mathrm{~mm}$ long, surface raised and sorediate when mature; apothecia and pycnidia not seen.

Branches roundish to ellipsoid in section, hollow in the center, $200-300 \mu \mathrm{m}$ in diam., cortex $40-50 \mu \mathrm{m}$, hyphae of medulla loosely interwoven, partly hollow, c. $6-9 \mu \mathrm{m}$ in diam., verrucose on the surface; photobiont green algae, photobiont layer $25-30 \mu \mathrm{m}$ thick.

Chemistry - Medulla and cortex $\mathrm{K} \pm$ yellow, $\mathrm{P}+$ slowly orange red, $\mathrm{C}-\mathrm{KC}+$ yellow, containing usnic acid, virensic acid and protocetraric acid (trace).

Known distribution - Growing on bark of Abies delavayi in the alpine coniferous forests above $4000 \mathrm{~m}$. Endemic to Yunnan Province.

Notes - Alectoria spinosa is characterized by sorediate pseudocyphellae and spinules growing over soralia, which is a rather unique character in the genus Alectoria. It resembles the North American isidiate A. imshaugii, but the latter contains thamnolic and squamatic acids, subpendent thallus $5-8 \mathrm{~cm}$ long, and it has isidiiform spinules on the thallus. It might be confused with the rare sorediate morphotype of $A$. sarmentosa by having soralia, but the latter species has no spinules, the thallus is pendent $(<80 \mathrm{~cm}$ long), and it contains alectoronic acid. Alectoria ochroleuca differs from this new species by the yellowish green thallus with blackened apices, without spinules and soralia on the thallus surface, and contains diffractaic acid as its main compound (Brodo and Hawksworth, 1977).

Alectoria spinosa might be confused with Bryoria and Oropogon due to the light yellowish brown thallus color, it does not look like typical Alectoria, which are pale greenish yellow. It does, however, contain usnic acid, like a typical Alectoria. Alectoria spinosa is also similar to some Sulcaria species with a yellowish thallus, but it lacks longitudinal furrows on the branches. The phylogenetic tree supports placement of A. spinosa in Alectoria.

Additional specimens examined - CHINA. Yunnan: Lijiang Co.: Jiuhe Village, Laojunshan Mt., 26 $37^{\prime} \mathrm{N}, 9^{\circ} 42^{\prime} \mathrm{E}$, alt. $4010 \mathrm{~m}$, on bark of Abies delavayi, 22 May 2011, Wang \& Liang 1132083, 11-32085, 11-32102.

Alectoria ochroleuca (Hoffm.) Mass., Sched. Crit. Lich. Ital.: 47. 1855.

Figs $2 \mathrm{C}-\mathrm{D}$ $\equiv$ Usnea ochroleuca Hoffm., Descr. Adunbr. Pl. Lich. 2(1): 7. 1791.

Description - see Wang et al. (2014).

Notes - This species is characterized by the dull yellowish green surface with blackened apices; conspicuous white pseudocyphellae, verrucose medullary hyphae and usnic acid. It is similar to Sulcaria sulcata (Lév.) Bystrek, but the latter species differs in having longitudinal furrows on the surface and in lacking usnic acid.

Selected specimens examined - CHINA. Yunnan. Deqin Co.: Mt. Baima, $4000-4800 \mathrm{~m}$, under Rhododendron shrub, Li S. Wang 94-15361, 93-13500, 81-22849, 85-8898, 81-22850, 858891, 84-41a. Xizang: Demula Co.: alt. 5000m, 1976, Zang 9419; Yadong Co., alt. 4760m, on rock, 1975, Zang 44. Inner Mongolia: Daxinganling, alt. 1460m, on rock, 1951, Li S. Wang 1905. 


\section{Key to Alectoria in China}

1. Thallus without soredia, medulla with diffractaic acid ( $\mathrm{CK}+$ gold yellow)... Alectoria ochroleuca

1. Thallus sorediate, without diffractaic acid, contains virensic acid $(\mathrm{CK}-)$...... Alectoria spinosa

Table 1 Specimens used in this study, newly obtained sequence numbers are in bold.

\begin{tabular}{|c|c|c|c|}
\hline Taxon & Locality & Voucher specimen & Accession No. \\
\hline Alectoria imshaugii & Finland & Helsinki 00014, BM & EU282496 \\
\hline A. spinosa & China, Yunnan & 11-32085, KUN-L & КМ042886 \\
\hline A. spinosa & China, Yunnan & 11-32083, KUN-L & KM042887 \\
\hline A. nigricans & Sweden & Lundqvist 8377 , UPS & DQ979996 \\
\hline A. ochroleuca & Austria & Wedin Aug. 1988, BM & DQ979997 \\
\hline A. ochroleuca & China, Yunnan & 10-31920,KUN-L & KM979761 \\
\hline A. sarmentosa & Sweden & Wedin 6350, UPS & DQ979998 \\
\hline Bryoria bicolor & not known & J. Hermansson 14110, UPS & HQ402692 \\
\hline B. furcellata & Canada: Alberta & Colberg \& Prokopetz s.n., UBC & HQ402724 \\
\hline B. nadvornikiana & China, Yunnan & 06-26535, KUN-L & HQ402715 \\
\hline B. rigida & China, Yunnan & 06-26208, KUN-L & HQ402703 \\
\hline B. tenuis & not known & S. Velmala $64, \mathrm{H}$ & HQ402694 \\
\hline B. trichodes & Russia: Kamchatka & D. Himelbrant EL 6, H & HQ402708 \\
\hline Oropogon americanus & Costa Rica & Unknown & КС667030 \\
\hline O. caespitosus & Mexico & A_6396 & KC667033 \\
\hline O. colibor & Costa Rica & 6715_1 & КC667042 \\
\hline O. mexicanus & Mexico & Esslinger 18532, TLE & JQ813834 \\
\hline Sulcaria sulcata & China, Yunnan & 09-31154, KUN-L & KM979759 \\
\hline S. virens & China, Yunnan & 10-31527, KUN-L & KM979760 \\
\hline Gowardia arctica & Unknown & Mattsson 5142, UPS & EU282505 \\
\hline
\end{tabular}

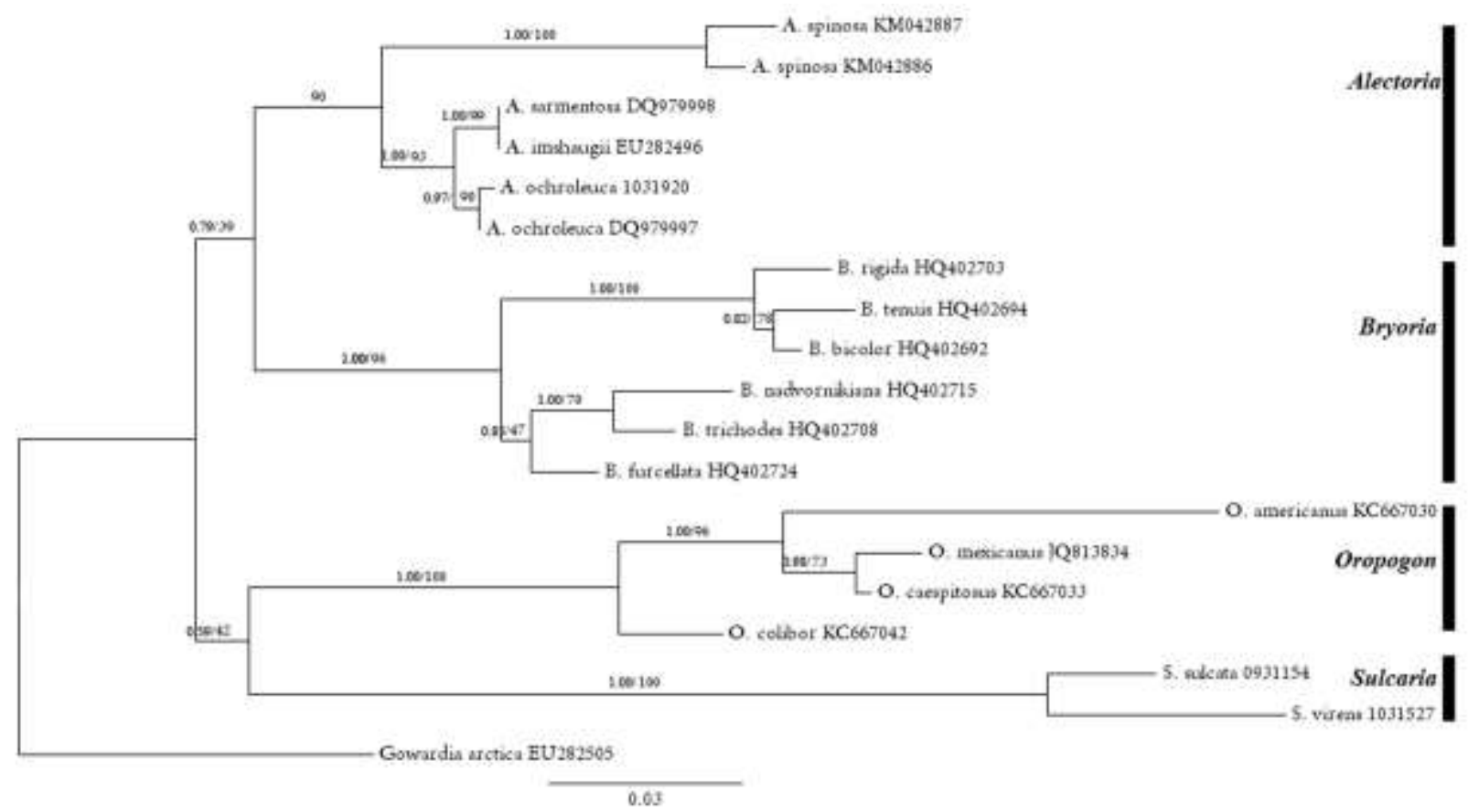

Fig. 1 - Phylogenetic tree inferred from Maximum Likelihood (ML) analysis based on the ITS data. Support values are posterior probabilities (from Bayesian Inference) followed by ML bootstrap frequencies. 


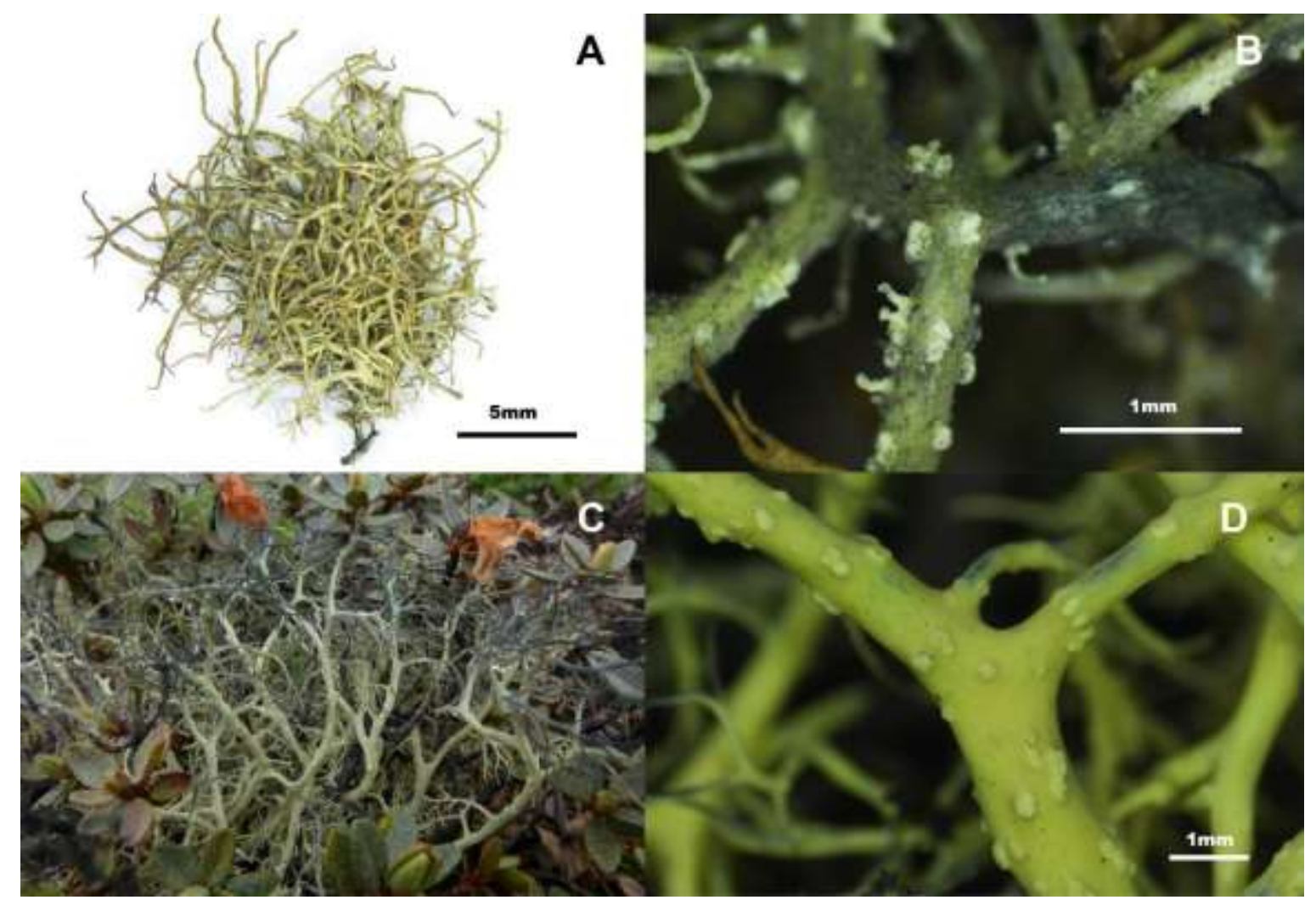

Fig. 2 - A Thallus of Alectoria spinosa. B Spinules on the soralia of A. spinosa. C Habit of A. ochroleuca. D Pseudocyphellae of A. ochroleuca.

\section{Acknowledgements}

We're grateful to Prof. Bernard Goffinet (University of Connecticut, USA) for revising the English composition. This study was supported by a grant from the National Natural Science Foundation of China (No. 31170023, 31370069, 31400022), West Light Foundation of The Chinese Academy of Sciences, Foundation of Key Laboratory, CAS (KLBB-201210, 201306), and Flora Lichenum Sinicorum (KSCX2-EW-Z-9).

\section{References}

Arup U. 2002 - PCR Techniques and Automated Sequencing in Lichens. Pages: 392-411. In: I. Kranner, R. P. Beckett \& A. K. Varma (eds). Protocols in Lichenology: Culturing, Biochemistry, Ecophysiology and Use in Biomonitoring. Springer-Verlag, New York.

Brodo IM, Hawksworth DL. 1977 - Alectoria and allied genera in North America. Opera Botanica 42: $1-164$.

Castresana J. 2000 - Selection of conserved blocks from multiple alignments for their use in phylogenetic analysis. Molecular Biology and Evolution 17(4): 540-552.

Ekman S. 1999 - PCR optimization and troubleshooting with special reference to the amplification of ribosomal DNA in lichenized fungi. Lichenologist 31: 517-531.

Edgar RC. 2004 - MUSCLE: multiple sequence alignment with high accuracy and high throughput. Nucleic Acids Research 32: 1792-1797.

Gardes M, Bruns TD. 1993 - ITS primers with enhanced specificity for basidiomyctes. Application for the identification of mycorrhizae and rusts. Molecular Ecology 2: 113-118.

Hawksworth DL. 1970 - Chemical and nomenclatural notes on Alectoria (Lichens) II. Taxon 19 (2): 237-243.

Halonen P, Myllys L, Velmala S, Hyvärinen H. 2009 - Gowardia (Parmeliaceae)-a new alectorioid lichen genus withtwo species. The Bryologist, 112(1): 138-146. 
Orange A, James PW, White FJ. 2001 - Microchemical methods for the identification of lichens. British Lichen Society, London.

Posada D. 2008 - jModelTest: phylogenetic model averaging. Molecular Biology and Evolution 25 (7): $1253-1256$.

Ronquist F, Huelsenbeck JP. 2003 - MrBayes 3: Bayesian phylogenetic inference under mixed models. Bioinformatics 19: 1572-1574.

Stamatakis A. 2006 - RAxML-VI-HPC: Maximum likelihood-based phylogenetic analyses with thousands of taxa and mixed models. Bioinformatics 22: 2688-2690.

Tehler A, Wedin M. 2008 - Systematics of lichenized fungi. Pages 336-352. In: Nash III (ed.). Lichen Biology. Cambridge University Press, Cambridge.

Wang XY, Liu D, Li JW, Harada H, Wang LS. 2014 - Lichen Flora on the Genera Alectoria, Pseudephebe, and Sulcaria (Lichenized Ascomycota, Parmeliaceae)from the Hengduan Mountains in China (4). Proceedings of the 2012 International Conference on Applied Biotechnology (ICAB 2012). Lecture Notes in Electrical Engineering, Volume 250: 10951105.

Wei JC. 1991 - An Enumeration of Lichens in China. International Academic Publishers, Beijing.

White TJ, Bruns TD, Lee S, Taylor J. 1990 - Amplification and direct sequencing of fungal ribosomal DNA genes for phylogenetics. Pages: 315-321. In: Innis, M. A., Gelfand, D. H., Sninsky, J. J. \& White, T. J. (eds). PCR Protocols: a Guide to Methods and Applications. Academic Press, San Diego.

Wu JN, Wang LS. 1992 - Alectoriaceae and Anziaceae lichens from Yunnan Lijiang region. Acta Botanica Yunnanica 14(1): 37-44. 